\title{
History and the Shaping Of Nigerian Leadership
}

\author{
Mile, Terwase .J. (Ph.D) \& Jeje, Eunice S.A. (M.A) \\ Federal University, Dutsinma, Faculty of Arts, Management and Social Sciences, \\ Department of History and Strategic Studies. PMB 5001 \\ Dutsinma, Katsina State, Nigeria.
}

\begin{abstract}
Nation building through leadership for greatness in new times of any entity demands concrete roles and efforts, particularly, of the 'what have' of History of that entity. The shaping of future leadership for any entity like Nigeria in a new time is recognized to demand a similar task of History. History's provision of the when, where, how and what of things as well as its consciousness raising activity and lessons of motions and above all, of its revolutionary endeavors to a great extent, combines in shaping nations and future leadership for greatness. This paper through a bold and concrete historical perspective identified and examined the nature and extent of Nigeria's inherent political and particularly, leadership problems and proffered history's problem solving approach through a popularly grounded revolutionary methodological perspective.
\end{abstract}

Keywords: Colonialism, History, Leadership Question, Nigeria.

\section{Premise}

In order to succeed in bringing about significant, purposeful shaping or changes in any entity or product of that entity, it is necessary to have an understanding of what that entity actually is, or its product, its formation and the changes there in over time. This is a universal premise, vigorously pursued by Usman Y.B (1994). This historical or scientific premise is also the basis of the primacy of genetics in the study of all living organisms, and of particle physics in the study of all matter; and phenomenal advances made in these disciplines to human knowledge and human capabilities up to the present existence.

Clearly, the theme, History and the shaping of Nigerian leadership seem to rightly suggest that there is first and foremost problem of leadership in Nigeria, secondly and above all, that this elementary but primal significance of historical or scientific premise does not, however, seem to have effectively registered in influential, political and intellectual circles in Nigeria. This basically seems to be at the root of inability to understand the nature of Nigerian political- economy, its composition and its motion. Thus, much reliance on impressionistic personalized and alien experiences as well as abstractive assumptions of what Nigerian polity it has many times brought several ambitions to grief, often with tragic consequences for the whole country.

In this way, the problems and issues that we face in any given situation should be situated in a larger, dynamic context to save present realities in order to be able to actually see them for what they are, in their meaning and significance and relevance over time.

\section{Inside Nigerian History and Polity}

History has it that in its earliest usage the polity named Nigeria was intended to be applied to the northern part of the country, in order to distinguish those parts from the British Colony of Lagos and the Niger Coast Protectorate. In a letter to The Times of London $8^{\text {th }}$ January, 1897, Flora Shaw, the wife of Frederick Lugard, suggested the name "Nigeria" as a:

Shorter title for the agglomeration of pagan and Mohammedan States

Which have been brought by the exertions of the Royal Niger Company

Within the confines of a British Protectorate, and thus need for the first

Time in their history to be described as an entity by some general name

(which) may serve to differentiate them equally from the British Colony of

Lagos and the Niger protectorate on the coast and from the French territory

of the upper Niger.

The context in which Flora Shaw wrote these lines is significant in understanding the different levels of which political entities exist. On $1^{\text {st }}$ January, 1900, the British government proclaimed the existence of two new colonial entities, namely, the Protectorate of Northern Nigeria and the Protectorate of Southern Nigeria, alongside, but distinct from the Colony and Protectorate of Lagos.

This was followed in 1906 (with the second of these series of amalgamations), when the Colony of Lagos was merged with the Protectorate of Southern Nigeria to form a 
single colonial entity known as the colony and protectorate of Southern Nigeria which legally made Lagosians, Nigerians, six years after all the others except those from Northern Cameroon who joined after the 1961 plebiscite, had become Nigerians.

The prominence given to what happened in 1914 as the amalgamation arose out of the politics of the British colonial machinery. The 1914 amalgamation was given its prominence in order to psychologically and politically obstruct the emergence of a pan- Nigerian movement for independence by deepening and emphasising that the basic division of Nigeria is between the "North" and the "South" sowing leadership problem in the polity.

At 1960 when Nigeria got her independence, many a man both in Nigeria and outside hoped that she would be the showcase of democracy and political stability in Africa and her leaders, a unique case of leadership excellence. The expectation was borne out of her vast reservoir of human and natural resources. But what does one see today is a situation whereby destruction forces held sway. A country without national consciousness loyalty or identity; a country torn by the cleavages of tribe and ethnicity; utterly ravaged by a civil war barely five years after independence; a country which during its fifty-two years of independence, has seen five military coups, five attempted ones, six military leaders and only nine years without soldiers in power; a country beserted by election malpractices, widespread corruption, fierce and frequent religious riots, social and communal chaos, thugerism, tension arms built up; a country where the governed have lost confidence and hope in government and above all, its leadership.

Thus, it is clear that many actors on the stage, past, present and those being prepared in retrospect of the future all have a share of the blame in varying degrees. In chronological and basic historical order, the colonial power (who formed our political foundation) the Nigerian politicians (both those in the past and in the present making in the new millennium) and the military (all who have no clear knowledge of our polity) are all basically responsible for installing leadership problem. The colonial power had the best opportunity to weld the various peoples that constitute Nigeria together but it allowed it to slip by the introduction of indirect rule immediately the country was brought under British rule. Usman, Y. B. (1994) maintains that in vain did Governor Clifford, who succeeded Lugard, try to inform the colonial office of the retrogressive nature of indirect rule. Elsewhere, a critic of indirect rule, Margery Perham in her book Indirect rule in Nigeria established pertaining this that what was an expedient and improvisation was raised into an ideal, a policy; a dogma, and a bible for African administration. Any junior officer who dared query how, if indirect rule is to go on... was immediately branded temperamentally unsuited for life in Nigeria. The result was that British officers became too liberal and did not want to rule. They were paternalistic and served the interests of their districts rather than those of the Nation. They were "Northerners", "Easterners" and "Westerners" rather than Nigerians. This colonial attitude has continued even in their retirements. They have separate associations for those who served in the North, East and West. This colonial attitude has continued even in their retirements. This greatly influenced the nature of Nigerian politics and leadership up to the present.

Moreover, the adhoc and fire-fighting manner in which power was transferred to Nigerians constituted another problem for the Nigerian polity and leadership. There was inadequate preparation and consultation in Nigeria as was the case in India. Both before and after independence, the British were still head of the Nigerian Army. Aguiyi Ironsi who was the highest army officer was only a Brigadier. In administrative service there were few senior officers. This brought about after independence the challenge of governance which strike a delicate balance between authoritarianism on the one hand, and anarchy on the other as Mazrui, A (1987) aptly observed

\section{....Nigeria's worst evils since independence are the danger of tyranny on the}

one side and the risk of anarchy on the other. Tyranny is too much government, anarchy is too little government. The tyrannical tendency is too often a centralization of violence. The anarchic tendency is basically a decentralization of violence - often neighbor against neighbor.

After independence, the inheritance elite or leaders believed that centralization was the only answer to the problem of political authority and control. This boomeranged and military coup played the convenient electoral role of changing governments. Thus Nigerian leaders and followers have found it difficult to strike a delicate balance between tyranny and chaos. The first shock to many Nigerian leaders after independence was their schooling in the colonial dyarchical government in the terminal phase of colonialisation. The new parliamentary system they were to implement did not give them as much as it gave to their predecessors. Therefore, if the colonial Governor- General combined legislative and executive powers, the new system had checks and balances and division of functions between the executive, legislature and judiciary. Schooled in authoritarian colonial political culture, it was not easy making a transition to parliamentary democracy with values of participation, accommodation of political opponents and even the spirit of tolerance. In addition, 
political and military powers in Nigeria were even fused, and there were hardly institutionalized opposition (as was in the Westminster model).

Another cause of Nigerian leadership failure and political instability derives from the crises of legitimacy. Basically legitimacy has two solid aspects. It involves the right to rule. Thus the question here is that; do our leaders have the right to rule based on the accepted constitutional provisions or political culture? Often the right to rule has caused us much political furore, as the fact that whether the leader is ruling rightly. To rule rightly, the leader must "deliver the goods" promised or assumed, at least in terms of the expectations of the people. Unfortunately many Nigerian leaders, even under "democratic" regimes have been able to even boast of ruling rightly not to talk of their being easily removable, even though through the ballot box!. Here in lies another source of instability based on the politics of leadership successions.

Of the transferred institutions at independence, two of them stand out- the political parties and the military. The political parties were expected to mobilize the populace for the purpose of aggregating and articulating their interests and providing alternative governments. They failed in this role and like the military, had transferred the institution without accompanying proper values in political bargaining and rule. The second institution is the military which was meant to defend the integrity of the state, to be a professional this political institution was also transferred wrongly, without adequate values of professionalism. Worst of all the Nigerian military had a short period to imbibe values of military professionalism not to talk of those of political leadership even before they intervened in Nigerian leadership and politics.

Thus at the end of the day, History has clearly revealed that in Nigeria, military regimes which came in as political physicians ended up as political patients of the same ailments they were set out to cure.

But now that Nigeria is once again in the new time on her road to democracy and democratic leadership. We feel strong to proffer through Nigerian history that Nigerian democracy should first and foremost be strictly domesticated so that no foreign elements could not add a new trouble, if it is to take proper root in the modernizing political arena, with rule of law, accountability and legitimacy. Moreover, the primacy of politics should first and most be balanced with the primacy of economics. This is because democracy cannot be practically steered on an empty stomach! All these cautions are relevant or of assumptions and promises of a full stomach because History has already recognized clearly that transition programs in Nigeria, are still inherently more concerned about political order and laying the political foundations of western democracies what looks like a new authoritarianism which is the primary objective of the post-colonial state in the creation of national bourgeoisie with the use of fundamentally corrupt and undemocratic practices in its evolution this constituted another problem of leadership for the country in the present times.

\section{The quest for shaping Nigerian leadership}

History has recognized that there is clearly the inevitability of instability in Nigeria. This is because the artificiality of the colonial independence settlement as well as the present day alien democratic prescriptions only makes necessary a power struggle to rectify imbalances in the politics and leadership of Nigeria. This has made obvious some credible points, that the economic problems facing Nigeria contain a colonially built-in frustration which inherently threatens leadership stability. Moreover, that the quality of politicians who have been emerging and have just emerged as if from pre-technological traditions, whose attitude to power are still formed in colonial agitational politics no doubt, offer hope for capable leadership in the work of governance of this country.

From History Bangura, Y. (1990) pointed out, the local politicians had from early post independence days refused to learn and know Nigerian history properly so as to understand the value of reverence for law and "respect for the rules of the game". In a similar way, O Connell, J. (1976) maintained that a valuable part of political experience in a mature tradition is the lesson that politics becomes destructive for nearly all its participants, once constitutionalism- which is a mixture of a just or acceptable law and the rulers of the game- is flouted. It does seem that only in the continuing vicissitudes of the politics of independence can the new political classes and leaders learn that without tolerance and conciliation politics and leadership becomes dangerous for all its participants. Two further complicating factors, besides the want of experience, impede leadership learning. The first is the authoritarianism of the colonial tradition. The second is the reluctance of those out of power to limit themselves to law and the rules of the game. The trouble is that most of Nigerian politicians are incompetent, corrupt and communal. They are incompetent in the sense that they possessed too few modernizing attitudes and formal skills for the function of governing or leadership. As Dudley, B.J (1997) made reference to this point pertaining Northern Nigerian politicians in relation to skills required for a new representative system that; "men trained to play draughts are led to make such same moves in a game of chess, and the result is neither draught nor chess". Thus, to attempt to graft the regulative rules of a game ( of a parliamentary system of government) on to a different set of constitutive rules, (an alien social structure) where these are incompatible, will lead to the ensuring result being neither the one nor the other but a new game with its own rules, ensuring corruption and communalism of leaders especially, concerning financial morality and the 
psychology of corruption steaming from the breakdown of trust and predictability in political transition, and as well, leading to political instability and lack of leadership which the country is facing towards creating a greater nation in the next millennium. This necessitated a call on History in the shaping of Nigerian leadership.

\section{Lessons from History as a solution for leadership problem}

History is the society's memory. It is a process which stimulates consciousness raising activity. History is used for all kinds of purposes for both social and political engineering. History itself is grounded in objectivity. This becomes very important in a society like Nigeria, where nation- building towards a greater Nigeria is a consuming task. However, historical objectivity does not detract from the issue of relevance to society. Indeed, if all actions are historically conditioned and informed, it allows that history can be applied to day to day issues. Thus, history commands some unique skills for resolving problems. It possesses all the objective characteristics such as possession of skills peculiar to it, which the society wants and the ability to practicalise the skills in an atmosphere of turbulent economic, social and political crisis.

Historical professionalism can be used to a great advantage in public commission of enquiry, cultural studies, comparative developmental studies, ideological formulations, planning and entertainments and above all for policy makers and leaders. History is a process of continuous interaction with the facts and an unending dialogue between the past and the present which links an un-cuttable bridge with the future. Thus, through history the past, present and future form a continuum

Through history it is clear that the overwhelming large part of conscious human action which is based on learning, memory and experience (political or otherwise) will regulate mechanisms for constantly confronting the past, present and future. People cannot help trying to forecast the future by some form of reading the past. They have to, the ordinary processes of conscious human life, not to mention a special matter of political leadership and policy, requires it.

By its very nature history implies looking into the future. This activity rests to a great extent on some sort of inferences about the future from what has happened in the past that is to say from history. History ought therefore to have something relevant about shaping of the future generally because there is no line which divides the two (i.e. the past and the future). However somewhere between the two there is a notional but constantly moving point which, if you like, you can call "the present"; as every pollster knows, we can ask the present any answerable question, though by the time it is answered and recorded, if will also, strictly speaking, belong to the past, albeit the recent past. Nevertheless the past, present, and future form a continuum. And history is constantly foreseeing, if only retrospectively. Through which the future happens to be the present or the past, even the most conventional and unscientific historians and laymen or common sensers are all confronted with this reality. The psychological equivalent of "worst case" thinking is paranoia or hysterical. Indeed it is as times of tension and fear such (political and leadership) crisis that we live in, that hysteria and ahistoricity combine... the worst is expected, not only among those professionally committed to envisaging it like military men, secret service politicians of most respected order and the thriller- writers they so often imitate but also among quite sensible people who develop geopolitical fit at the thought of dismemberment. And, more seriously, our failure to understand the Nigerian history and its political history particularly becomes mechanized, and we set up automated systems geared to the worst case, which are set in motion by signs which mistakenly read political collapse and lack of leadership. Short of the intervention of practical history, only equally automatic technical crosschecks showing that the signs have been mechanically misread can stop the process of leadership destruction. Such alarms are, in a sense, the hair raising reduction ad absurdum of facing the future ahistorically. I don't actually expect that if or when war breaks out in Nigeria it will be triggered off by a blind technical malfunction. But the fact that it should, and just possible might, does illustrate the indispensable role of historical rationality in assessing and shaping the future and future Nigerian leadership and the human action required to meet it. But all what we have been saying now belongs to the past.

\section{Conclusion}

How shall we conclude? History is not prophetic in the sense that it can or should try to unveil the headlines of next year's or next century's BBC world service news bulletins. Neither are we nor ought we to be in the eschatological department of prophesy business for desirable motive for shaping future Nigerian leadership. In any case it is not a good sign of the way the country is going when men lose confidence in the future, and gofferdammerung scenarios replace utopias. However, the historical job of finding out where we have come from and whither we are going ought not to be affected as a job by whether we like the prospective results.

Let us put it in paradoxical form, like so much of the future predicted in the past or present when it comes it may be unrecognizable, not because the shapings were wrong but because we were wrong to put a particular face and costume to the interesting stranger whose arrival we were told to expect. Thus line of leadership contemplation also pertains the issue of whether a new Nigerian leadership next election would commit to 
making sane leadership question and instill a foundation of further Nigerian leadership in the new millennium should be a secular state or not. This again has been revealed by history and properly shaped to reality. What has been clear therefore is that, the shaping of future Nigerian leadership can only be done through revolutionary means, even the more dangerous exercises in futurology which think out the unthinkable as an alternative to thinking out the thinkable can never but contemplate this naked reality. Only those with severely limited vision borne out of an intensely selfish focus on how to lay their hands on the largesse arising from Nigerian petrol dollar earnings and other fortunes can fail to see waves of change already shaping the future Nigerian leadership in the new millennium.

\section{References}

[1]. London Times $8^{\text {th }}$ January, 1897

[2]. Ali Mazrui, A. "Africa in Political Purgatory: The Crossroads between Collapse and Redemption" in Governance A Journal of the Institute of Governance and Social Research. Vol 1. 1998 Jos, Nigeria.

[3]. Abdullahi Mahdi, et al: Nigeria the state of the Nation and the way forward. Proceedings of the National Workshop Organised by Arewa House, Kaduna, Centre for Historical Documentation and Research of the Ahmadu Bello University, Zaria 2-3 February, 1994.

[4]. Usman, Y.B : Nigerian Realities and Options to the Year 2010 AD: A Discussant contribution to the paper presentation on "the place of Nigeria in the Global Economy by the year 2010". By Chief E.A.O Shonekan, Ibadan, $19^{\text {th }}$ June 1997.

[5]. Usman, Y.B: History and the challenges of the Peoples and Polities of Africa in the $21^{\text {st }}$ Century. Lecture delivered at the $44^{\text {th }}$ Annual Congress of the Historical Society of Nigeria. University of Abuja, Nigeria. 1999.

[6]. Eric Hobsawn : Looking forward: History and the future. London. 1994

[7]. Yusuf Bangura : The crisis of Underdevelopment and the Transition to Civil Rule: Conceptualising the question of Democracy in Nigeria. Ahmadu Bello University Public Lecture. 1984

[8]. Elaigwu, Isawa : Africa- Crisis and challenges: Towards a casual analysis. In Governance; A Journal of the Institute of Governance and Social Research. Vol 1 Jos. 1988

[9]. Jerome Udoji: Under three Masters, memoirs of an African Administrator. Spectrum books ltd. Lagos 1995

[10]. James O. Connell: The inevitability of instability. A Journal of Modern African Studies 5, 2. 1976

[11]. Sonni Gwanle Tyoden (ed): Nigeria: Youth Agenda for the $21^{\text {st }}$ century. Yakubu Gowon Centre for political studies. Sibon books ltd, Ibadan. 1998

[12]. Dudley, B.I: Traditionalism and Politics: A case study of Northern Nigeria in Government and opposition. London.1967

[13]. Metuge, W: "Democracy in Pheripheral Capitalist Societies: the African Case" in Egite, Oyovbaire S. (ed). Journal of Political Science Ahmadu Bello University, Zaria. 1978

[14]. Connell, J: "The Political Class and Economic Growth" Nigerian Journal of Economic and Social Studies, Vol 8 March.1966

[15]. Connell, J:" The Inevitabilty of Instability", Journal of Modern African Studies, vol 5. 1967

[16]. Osoba, S: "The Nigerian Power Elite, 1952-1965" in Gutkind and Wallestein (eds) African Social Studies: A Radical Reader, Heinemann, London. 1977

[17]. Oyovbaire, S.E.: "Some Observations on Dr. Barongo's Paper: 'Understanding African Politics-The Political Economy Approach'", Staff Seminar, Department of Political Science, Ahmadu Bello University, Zaria. 1978

[18]. Rev. Fr. Kukah M.H: "Political Stability, the Leadership Question and the Inevitability of Instability" in Not in our Character Proceedings of the national Seminar on the appraisal of the Social and Moral image of the Nigerian society. Kaduna. 1998 